\title{
Kemampuan Mahasiswa dalam Mengembangkan Alat Permainan Edukatif berbasis Perkembangan Anak: Peran Kelompok Belajar APE
}

\author{
(Students' Ability in Developing Educational Toys based on Child Developments: \\ The Role of APE Study Group)
}

Syarfina

Pendidikan Islam Anak Usia Dini, IAIN Langsa syarfina@iainlangsa.ac.id

First received: 31 May 2020

Revised:
09 June 2020

Early childhood educators are not only expected to be professional in teaching but also in developing educational toys (ET). As a prospective Early Childhood Education (ECE) teacher, students who are taking lectures in the ECE program should have an early opportunity to increase their potential in developing ET. However, the ability of students to develop ET is still limited, and the design does not cover the entire content of child development. This study aims to recognize to what extent students' ability of Early Childhood Islamic Education programs can improve in developing educational toys based on all aspects of child development through participating in a study group. This research is a qualitative approach with 25 participants of the study group Data collection is conducted by observation, documentation, and interviews. The results showed that; (1) the ability of students in developing ET has emphasized all aspects of child development, (2) APE study groups can improve students' abilities and motivation in developing ET. The effectiveness of ET, which has been become products, can be identified in further research.

Keywords: educational toys, child development, study group

\begin{abstract}
Abstrak
Pendidik anak usia dini tidak hanya diharapkan profesional dalam hal mengajar, namun juga dalam mengembangkan alat permainan edukatif (APE). Sebagai calon guru Anak Usia Dini (AUD), mahasiswa yang sedang menempuh perkuliahan program studi Pendidikan Islam Anak Usia Dini (PIAUD) hendaknya memiliki kesempatan lebih awal untuk meningkatkan potensi mengembangkan APE. Namun, kemampuan mahasiswa dalam pengembangan APE masih terbatas dan belum mencakup keseluruhan konten perkembangan anak. Penelitian ini bertujuan untuk melihat sejauh mana kemampuan mahasiswa PIAUD dapat meningkat dalam mengembangkan APE berbasis seluruh aspek perkembangan anak dengan mengikuti kegiatan di kelompok belajar APE. Penelitian ini menggunakan pendekatan kualitatif dengan 25 peserta kelompok belajar APE Pengumpulan data dilakukan dengan observasi, dokumentasi, dan wawancara. Informan terdiri dari. Hasil penelitian menunjukkan bahwa; (1) kemampuan mahasiswa dalam mengembangkan APE sudah menitikberatkan pada keseluruhan aspek perkembangan anak, (2) kelompok belajar APE dapat meningkatkan kemampuan dan motivasi mahasiswa dalam mengembangkan APE. Keefektifan APE yang sudah berupa produk dapat dilakukan kajian lebih lanjut.
\end{abstract}

Kata Kunci: alat permainan edukatif, perkembangan anak, kelompok belajar 


\section{PENDAHULUAN}

Mengajarkan anak usia dini menggunakan mainan yang edukatif memiliki pengaruh positif dalam perkembangan anak (Goldstein, 2012; Page \& Thorsteinsson, 2017). Selain itu, mainan juga berfungsi untuk melibatkan pendidik untuk lebih dekat dalam berinteraksi sehingga dapat membantu anak lebih kreatif, kaya akan bahasa, memecahkan masalah, serta berpengaruh pada perilaku sosial anak usia dini (Goldstein, 2012; Healey \& Mendelsohn, 2019; Trawick-Smith et al., 2011).

Direktorat Pendidikan Anak Usia Dini (Depdiknas, 2003) mendefinisikan alat permainan edukatif sebagai sesuatu alat yang dapat digunakan sebagai sarana atau peralatan untuk bermain yang mengandung nilai edukatif (pendidikan) dan dapat mengembangkan seluruh kemampuan anak. Alat Permainan Edukatif (APE) merupakan mainan yang dirancang secara khusus untuk kepentingan pendidikan, sekaligus alat permainan yang dirancang untuk tujuan meningkatkan aspek-aspek perkembangan anak usia dini. APE juga merupakan bentuk permainan yang dirancang untuk memberikan pengalaman pendidikan atau pengalaman belajar kepada anak, baik permainan tradisional dan modern yang diberi muatan pendidikan dan pengajaran (Safiah, 2015). Alat permainan biasa, artinya, tidak memiliki unsur perencanaan pembuatan secara mendalam dengan mempertimbangkan karakterisitk dan aspek perkembangan anak.

Karena cara bermain dan mainan yang dipilih oleh seorang pendidik dapat memengaruhi tingkat perkembangan anak, maka perancang mainan memainkan peran dan potensi penting dalam mengembangkan alat permainan (Page \& Thorsteinsson, 2017). Mahasiswa pada program studi Pendidikan Islam Anak Usia Dini (PIAUD) merupakan para calon pendidik anak usia dini di masa depan. Pendidik anak usia dini tidak hanya diharapkan profesional dalam hal mengajar, namun juga dalam mengembangkan alat permainan edukatif (APE). Pengembangan merupakan proses pembuatan karya yang sudah dirancang/didesain sebelumnya, sehingga dapat menghasilkan produk (Seels dan Richey, 1994).

Sebagai calon guru Anak Usia Dini (AUD), mahasiswa yang sedang menempuh perkuliahan program studi Pendidikan Islam Anak Usia Dini (PIAUD) hendaknya memiliki kesempatan lebih awal untuk meningkatkan potensi mereka dalam mengembangkan APE. Namun, kemampuan mahasiswa dalam pengembangan APE masih terbatas dan belum mencakup keseluruhan konten perkembangan anak. Oleh karena itu, penelitian ini bertujuan untuk melatih mahasiswa PIAUD mengembangkan APE berbasis perkembangan anak melalui kelompok belajar APE.

Sebelum membuat produk berupa APE, mahasiswa mendesain terlebih dahulu APE yang memiliki indikator dalam perkembangan anak, baik dalam aspek nilai agama dan moral (NAM), kognitif, psikomotorik, Bahasa, dan sosial emosional. Dalam mendesain, terdapat pedoman desain yang harus diperhatikan terkait konten, desain visual, juga interaksi (Kara \& Cagiltay, 2020).

Penelitian dalam bentuk pelatihan pengembangan APE telah dilakukan oleh beberapa peneliti seperti (Halim, 2018), namun fokus subjeknya dilakukan pada guru-guru pendidikan anak usia dini 
(PAUD). Begitu pula pelatihan pembuatan APE playdough yang dilakukan oleh Sahjat (2018), sebagai sumber belajar kepada guru-guru PAUD di Kota Ternate. Selain itu, penelitian untuk meningkatkan kreativitas guru dalam mengembangkan APE juga dilakukan oleh Pusari dan Info (2014). Penelitian ini ditujukan kepada mahasiswa PIAUD yang diharapkan nantinya ketika menjadi pendidik anak usia dini, mereka sudah memiliki kemampuan dalam mengembangkan APE yang berbasis pada perkembangan anak.

Dalam mendesain APE berbasis perkembangan anak, dibutuhkan ide gagasan dan diskusi secara berkesinambungan. Dalam sebuah kelompok belajar, mahasiswa dapat bertukar pikiran dan membagi ide. Penelitian (Dr.Sirajul Haque, 2015) menunjukkan bahwa siswa lebih menyukai belajar secara kelompok karena dalam kelompok mereka mampu meningkatkan tidak hanya pengetahuan, tetapi juga kemampuan berpikir, percaya diri selama diskusi, serta dapat saling membantu sesama anggota. Kelompok belajar berpengaruh pada kesenangan dalam belajar dan tanggung jawab dalam tugas (Gökçe, 2011).

Kerja dalam kelompok efektif untuk kemajuan dalam pemahaman secara konseptual (Howe \& Tolmie, 2003). Investigasi keefektifan kerja kelompok yang dilakukan oleh (Sofroniou \& Poutos, 2016) juga menunjukkan hasil positif. Kerja kelompok memungkinkan mahasiswa untuk mengembangkan berbagai pemikiran kritis, analitis dan kemampuan berkomunikasi; kerja tim yang efektif; penghargaan dan rasa hormat pada pandangan orang lain, teknik dan metode pemecahan masalah, yang semuanya mempromosikan pembelajaran aktif (Bukaliya \& Mubika, 2015; Sofroniou \& Poutos, 2016). Dinamika kelompok yang efektif juga merangsang minat serta meningkatkan strategi manajemen kelas (Petress, 2004). Oleh karena itu, kemampuan mahasiswa dalam mengembangkan APE berbasis seluruh perkembangan anak dikaji dalam penelitian ini melalui kegiatan kelompok belajar APE.

\section{METODE}

Penelitian ini menggunakan pendekatan kualitatif. Tujuan penelitian adalah melihat sejauh mana peningkatkan kemampuan mahasiswa program studi Pendidikan Islam Anak Usia Dini (PIAUD) dalam mengembangkan alat permainan edukatif (APE) yang berbasis seluruh aspek perkembangan anak dengan mengikuti kegiatan di kelompok belajar APE. Kelompok belajar APE diberi nama APE Study Club, yaitu kelas pengembangan APE melalui kegiatan secara kelompok. Metode pelaksanaan kelas pengembangan APE ini dilaksanakan selama satu bulan. Setiap minggu dijadwalkan dua kali pertemuan sehingga total 8 kali pertemuan.

Teknik pengumpulan data dilakukan dengan wawancara, observasi dan dokumentasi. Informan terdiri dari 25 mahasiswa PIAUD Fakultas Tarbiyah dan Ilmu Keguruan (FTIK) di Institut Agama Islam Negeri (IAIN) Langsa, Provinsi Aceh, yang mendaftar sebagai anggota APE Study Club. APE study Club menjadi wadah belajar pengembangan APE bagi mahasiswa program studi PIAUD IAIN langsa yang terdaftar sebagai anggota club.

Analisis data yang digunakan dalam penelitian ini meliputi: (1) pengumpulan data, (2) reduksi data, (3) penyajian data, (4) penarikan kesimpulan/verifikasi. Data 
hasil pengembangan APE di analisis secara deskriptif. Peneliti mengumpulkan data melalui rancangan pengembangan APE pada tahap awal dan tahap akhir serta observasi hasil produk.

Adapun tahapan yang dilalui peneliti sebelum kelas pengembangan APE dilaksanakan, antara lain:

1. Melakukan koordinasi dengan wakil dekan bagian akademik fakultas Tarbiyah dan Ilmu Keguruan serta ketua program studi PIAUD terkait program peningkatan kemampuan mahasiswa PIAUD dalam dalam Mengembangan Alat Permainan Edukatif (APE) Berbasis perkembangan anak;

2. Melakukan Koordinasi dengan Pengurus Himpunan Mahasiswa Jurusan (HMJ) PIAUD untuk melakukan kegiatan pengembangan Alat Permainan Edukatif (APE);

3. Mencanangkan lahirnya kelompok belajar APE yang diberi nama APE Study Club;

4. Membentuk pengurus APE study club dan melakukan sosialisasi.

5. Membuka pendaftaran kelas pengembangan APE; dan

6. Melaksanakan kegiatan kelas pengembangan APE melalui APE Study Club.

\section{HASIL TEMUAN}

Hasil penelitian di dapat setelah melalui langkah-langkah sebagai berikut:

1. Membagi peserta ke dalam kelompok

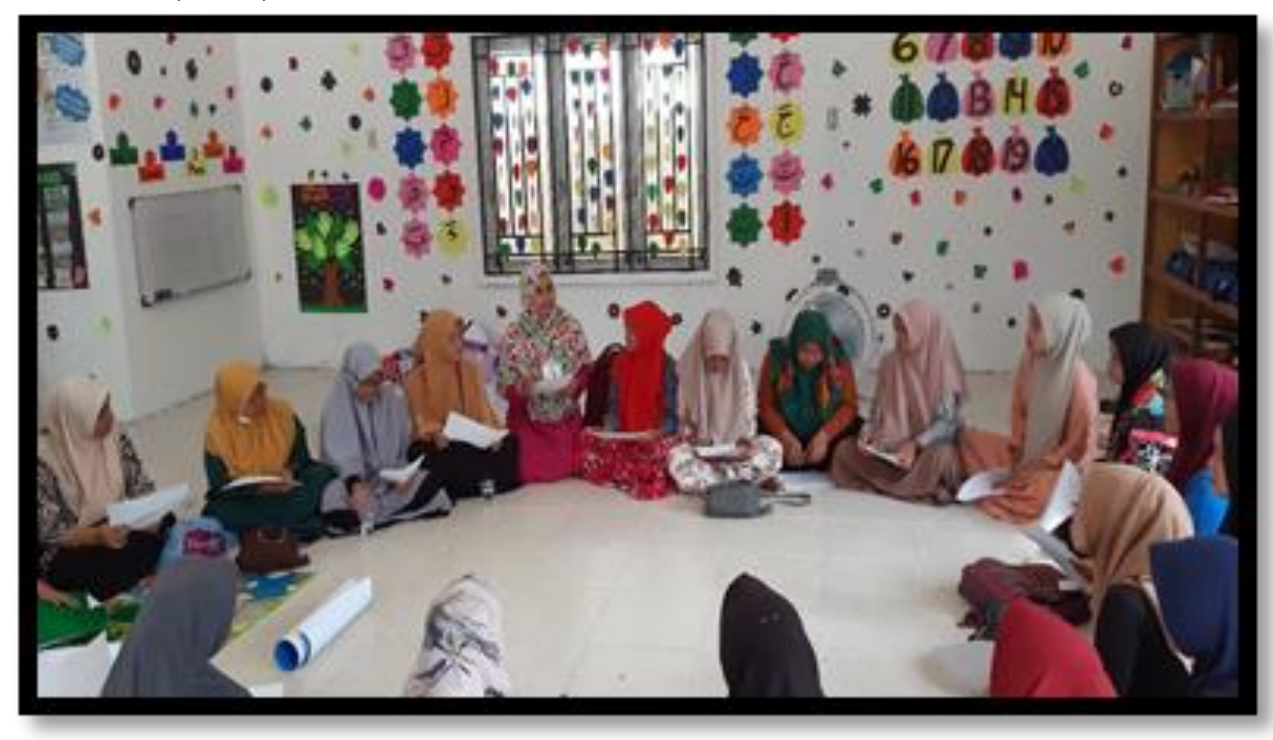

Gambar 1. Keseluruhan peserta dikumpulkan dan diberi arahan

Jumlah total mahasiswa yang mendaftar pada kelompok belajar APE study club adalah 25 mahasiswa, kemudian dibagi menjadi 5 kelompok, sehingga masing-masing kelompok berjumlah 5 orang.
2. Setiap kelompok mendesain APE yang akan dikembangkan. 


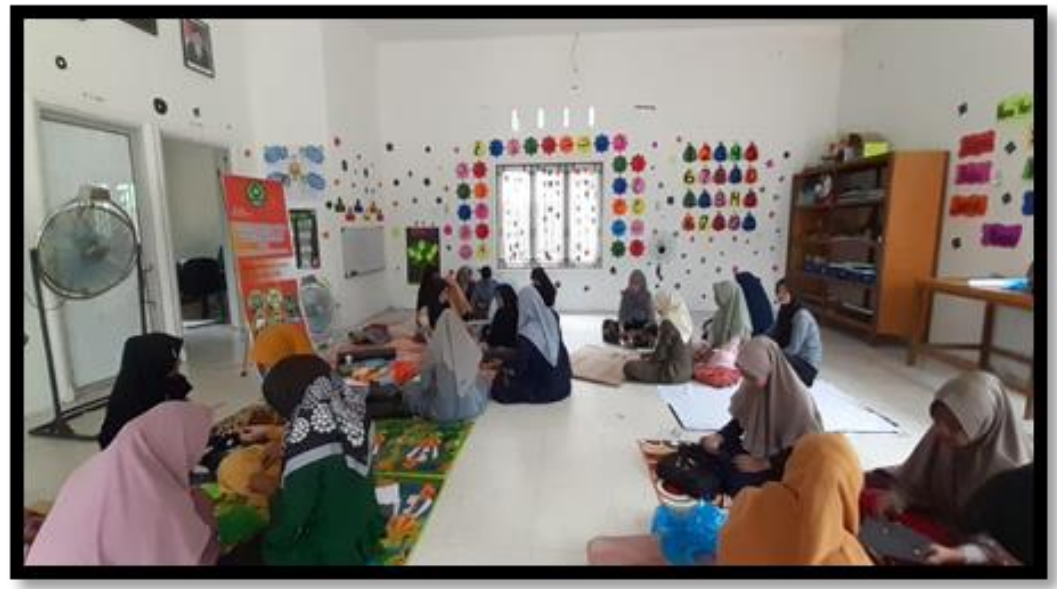

Gambar 2. Setiap kelompok mendesain APE yang akan dikembangkan

Setelah terbagi dalam 5 kelompok, c. Melakukan evaluasi tahap awal tiap kelompok dipersilahkan mendesain APE yang akan dikembangkan pada kertas rancangan yang telah disediakan.

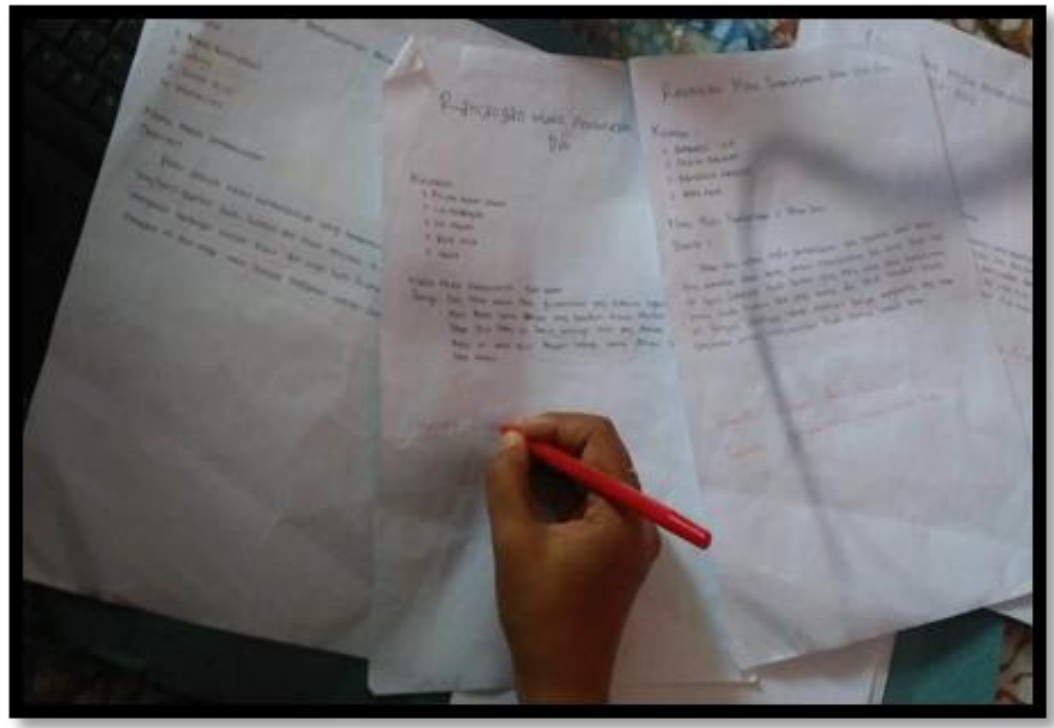

Gambar 3. Hasil desain APE tahap awal

Dalam rancangan APE tahap awal, mahasiswa hanya menuliskan nama APE serta deskripsi singkat tentang bagaimana bentuk APE. Ada yang menuliskan manfaat dari bermain APE tersebut, namun ada juga yang tidak. Aspek perkembangan yang dilihat pada satu
APE hanya mencakup satu konten perkembangan saja.

d. Mengajarkan konsep perkembangan serta cara mendesain dan mengembangkan APE 


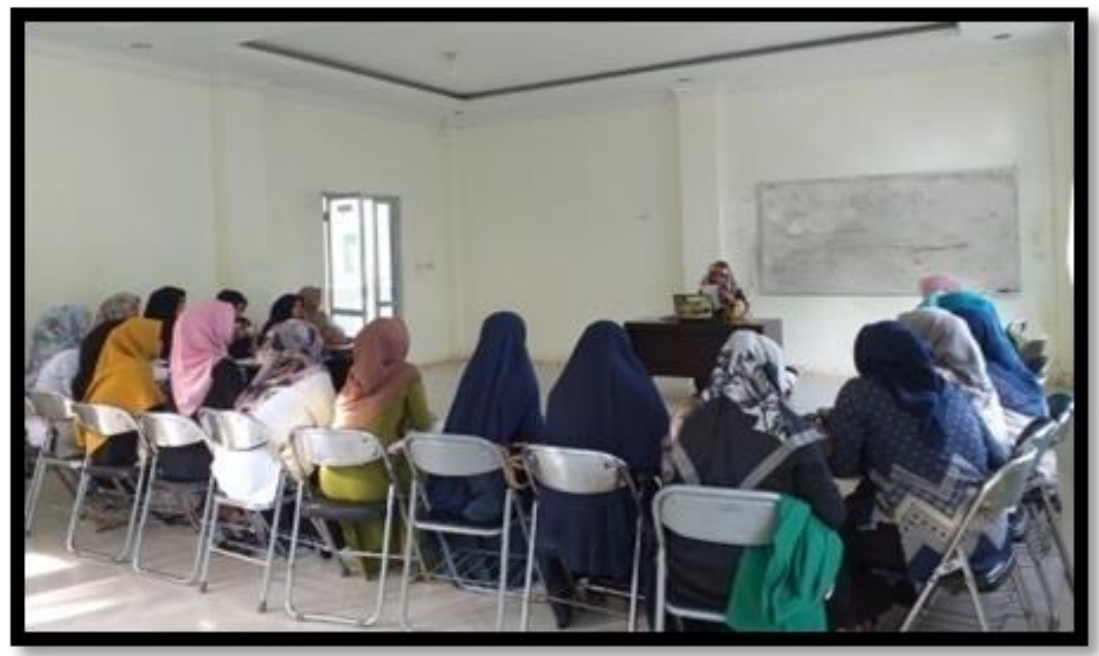

Gambar 4. Mengajarkan konsep perkembangan anak

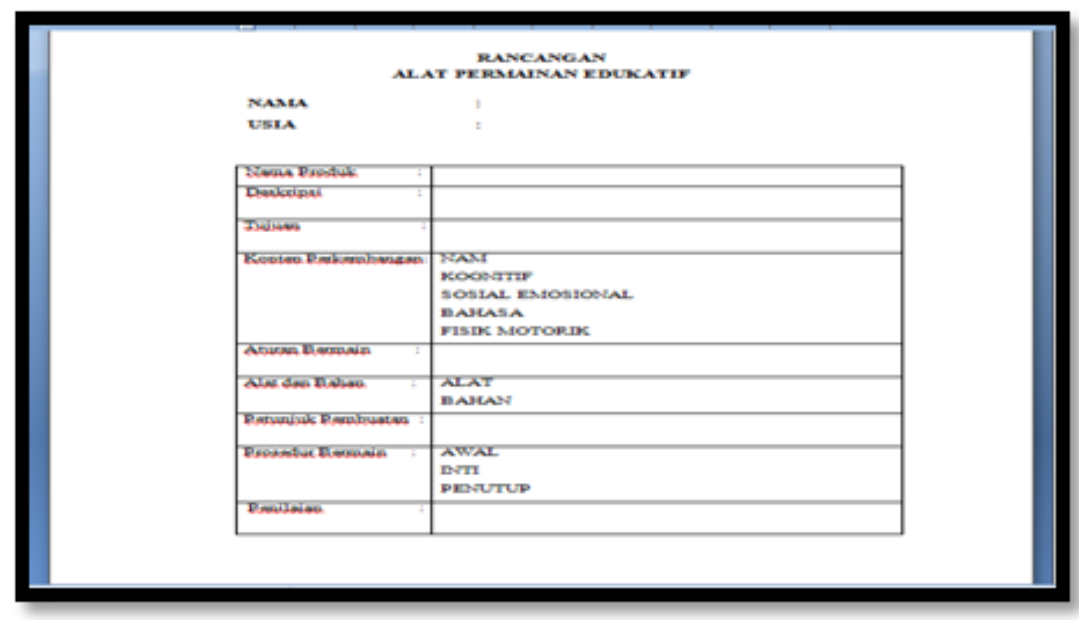

Gambar 5. Tabel Rancangan APE

Pada pertemuan selanjutnya, mahasiswa mempelajari cara mengembangkan aspek perkembangan dalam sebuah produk APE. Peneliti memberikan contoh tabel rancangan yang berisi nama produk, deskripsi produk, tujuan pembelajaran dengan produk tersebut, konten perkembangan yang akan dikembangkan melalui APE dari aspek nilai, agama, dan moral (NAM), kognitif, social emosional, bahasa, dan fisik motorik. Selain itu dalam tabel juga berisi aturan bermain, alat dan bahan yang digunakan, petunjuk pembuatan produk, prosedur bermain, serta cara penilaian. Indikator keberhasilan pembelajaran dengan menggunakan APE tersebut mengacu pada Standar Tingkat Pencapaian Perkembangan Anak (STPPA) PAUD Kurikulum 2013.

e. Mengevaluasi serta memberi kritik dan saran pada rancangan APE. 


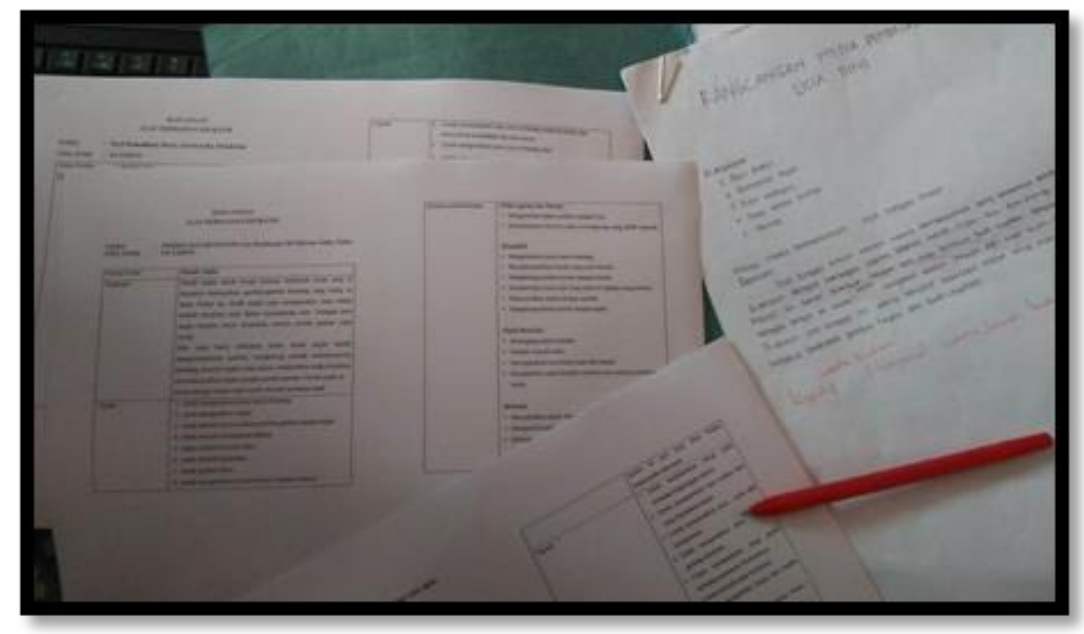

Gambar 6. Rancangan APE akhir

Peneliti memberi waktu kepada tiap kelompok dalam membuat rancangan APE sebelum dikembangkan menjadi sebuah produk nyata. Setelah peserta mengumpulkan rancangannya, peneliti megevaluasi dan memberi kritik dan saran pada rancangan. Peserta kemudian menyempurkankan rancangan Kembali.

f. Mempersiapkan alat dan bahan yang diperlukan untuk mengembangkan APE

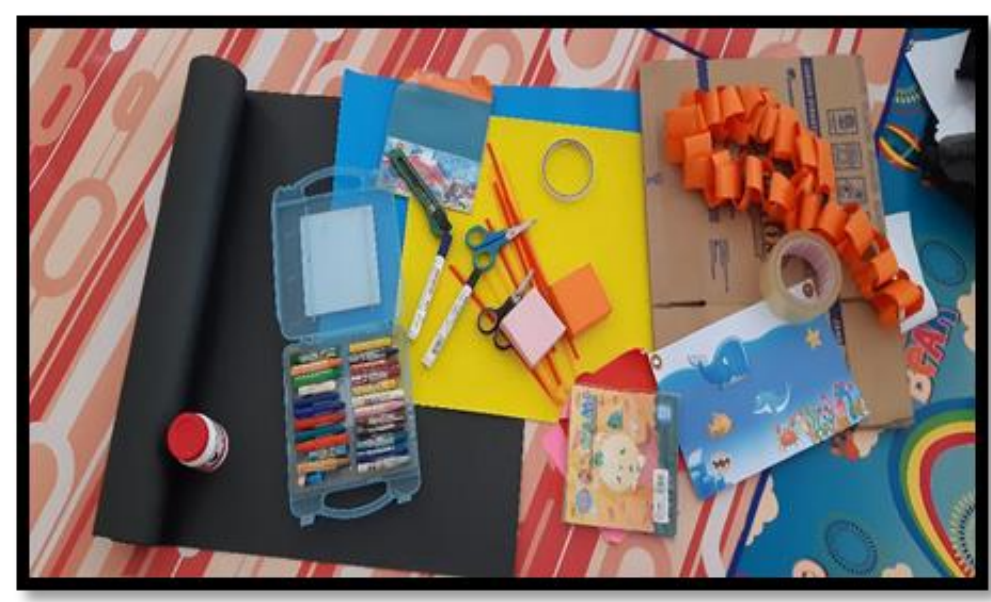

Gambar 6. Rancangan APE akhir

Kelas pengembangan APE menfasilitasi berbagai alat dan bahan untuk mengembangkan APE, namun peserta dipersilahkan membawa alat dan bahan yang dibutuhkan. g. Mengembangan

APE sesuai 


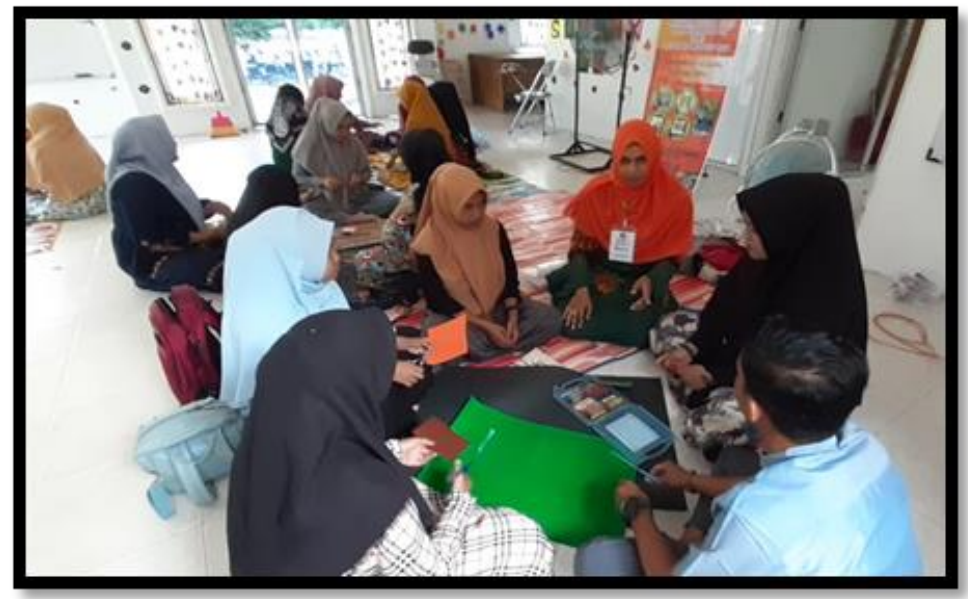

Gambar 7. Mengembangan APE sesuai Rancangan akhir

Peserta dipersilahkan membuat APE berbentuk produk sesuai desain APE yang sudah dirancang. Peneliti membantu mengarahkan pembuatan hingga menghasilkan produk APE. Beberapa temuan penelitian dari kegiatan APE Study Club, diantaranya:

1. Pada rancangan APE tahap awal, setiap kelompok sudah mendesain nama media dan deskripsi media. Namun, tujuan pengembangan APE tidak mencakup konten perkembangan secara keseluruhan Tujuannya hanya pada 1 aspek perkembangan. Deskripsi APE belum tergambar secara jelas, tidak terdapat cara pembuatan serta alat dan bahan apa saja yang dibutuhkan untuk mengembangkan APE. Tidak dicantumkan instruksi cara bermain dan tidak ada cara penilaian dari bermain APE.

2. Setelah tergabung dalam kelompok belajar APE, mahasiswa mendapat pelatihan cara membuat rancangan APE dan mendapat materi aspek perkembangan anak. Mahasiswa berdiskusi secara berkelanjutan dalam kelompok belajar hingga menghasilkan rancangan APE yang memperhatikan aspek perkembangan secara keseluruhan.

3. Pada rancangan tahap akhir, setiap kelompok memberi nama media secara unik, diantaranya: Surprise Box, Denah Angka, Kebun Binatang Pintar, Sea Box, dan Adventure City.

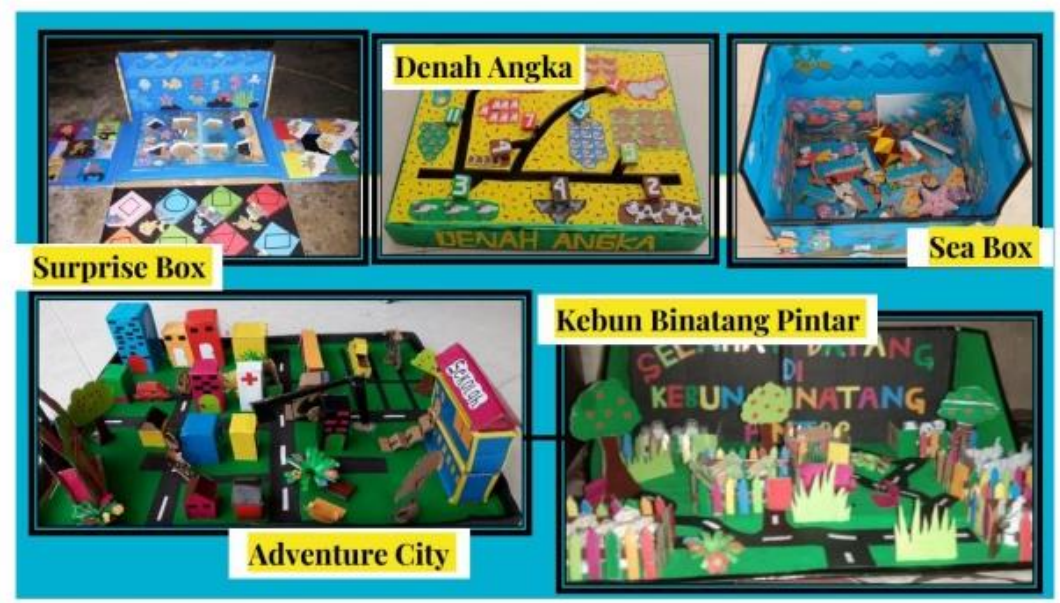

Gambar 9. Produk APE 
4. Indikator capaian kemampuan mahasiswa dalam mengembangkan APE berbasis seluruh aspek perkembangan anak terlihat dari rancangan APE yang teridiri dari: deskripsi media digambarkan secara lebih detail, tujuan pembelajaran dikonsepkan pada 5 aspek perkembangan anak, terdapat petunjuk pembuatan media, alat dan bahan yang diperlukan, prosedur bermain dan cara penilaian

8. Hasil wawancara dengan anggota APE study club menggambarkan bahwa kelompok belajar APE dapat meningkatkan kemampuan serta motivasi mahasiswa dalam mengembangkan APE.

\section{PEMBAHASAN}

Hasil desain APE tahap awal yang dirancang peserta APE belum mendeskripsikan APE secara jelas. Peserta akan sulit mengembangkan produk karena tidak terdapat cara pembuatan serta alat dan bahan yang dibutuhkan. Saat memilih bahan untuk mainan, penting untuk mempertimbangkan komunitas dan budaya anak-anak setempat (Gabriel Guyton, 2011). Banyak iklan yang mengajak konsumen berpikir bahwa mainan yang harganya mahal merupakan mainan yag baik. Pada kenyataannya, mainan terbaik adalah mainan yang dipilih berdasarkan kesesuaiannya untuk usia, perkembangan, dan minat anak (Gabriel Guyton, 2011; Trawick-Smith et al., 2011).

Dalam sebuah rancangan APE, diperluan adanya instruksi cara bermain yang tepat yang memungkinkan anakanak untuk menggunakan kreativitas mereka sambil mengembangkan imajinasi, ketangkasan, kekuatan fisik, kognitif, dan emosional mereka (Ginsburg et al., 2007). Cara bermain ini belum tergambar jelas Langkahlangkahnya pada desain APE awal. Menurut (Gielen, 2010) dalam penelitiannya tentang konsep penting dalam mendesain mainan, terdapat 3 hal yang perlu diperhatikan dalam mendesain permainan pada anak, yaitu: Pertama, aimlessness (tanpa tujuan). Hal ini menjadi elemen utama dari permainan agar pemain dimotivasi untuk aktivitas dengan minat pada proses, bukan oleh keinginan untuk hasil. Kedua, emphaty (empati). Berempati dengan kebutuhan, keinginan, preferensi, dan keterampilan anak-anak akan memberikan kualitas pada sebuah permainan. Ketiga, play value (Nilai bermain). Nilai dalam sebuah permainan merupakan istilah yang digunakan untuk menggambarkan keseluruhan kenikmatan seorang anak dengan mainan tertentu. Anak-anak akan bermain lupa waktu, namun tujuan yang ingin dicapai dapat terealisasi melalui desain APE dan cara bermain yang menyenangkan. Saat kelas pengembangan berlangsung, peserta mendapat kritik dan saran dalam memperbaiki rancangan APE pada bagian 'cara bermain; agar permainan terkesan mudah tanpa memperhatikan hasil, meskipun bagi seorang guru, permainan tersebut memiliki cara penilaian tersendiri.

Pada rancangan APE tahap awal, peserta tidak menonjolkan tujuan yang ingin ditingkatkan berdasarkan aspek perkembangan anak secara keseluruhan. Hal tersebut dikarenakan tidak semua peserta paham akan konsep perkembangan anak yang sebenarnya 
sangat sederhana namun mencakup segala mata pelajaran dalam satu tema. Namun, setelah mengikuti pertemuan kelompok belajar selanjutnya, peserta mendapatkan materi bagaimana merancang APE berbasis perkembangan anak dan mendapat kesempatan berdiskusi secara mendalam terkain rancangan produk, pemahaman konsep perkembangan anak pun menjadi hal utama yang sangat diperhatikan. Kerja dalam kelompok efektif untuk kemajuan dalam pemahaman secara konseptual Menurut (Howe \& Tolmie, 2003), kerja dalam sebuah kelompok bernilai efektif dalam meningkatkan pemahaman secara konseptual.

Mahasiswa saling bertukar pendapat dalam kelompok belajar sehingga dapat memperkaya pengetahuan dan memaksimalkan rancangan produk. Mahasiswa lebih menyukai belajar secara kelompok karena dalam kelompok mereka mampu meningkatkan pengetahuan, kemampuan berpikir, percaya diri, serta dapat saling membantu (Dr.Sirajul Haque, 2015). Kelompok belajar APE juga meningkatkan motivasi atau semangat belajar mahasiswa dalam mengembangkan APE berbasis perkembangan anak.

\section{SIMPULAN}

Berdasarkan hasil penemuan dan pembahasan, dapat disimpulkan bahwa kemampuan mahasiswa dalam mengembangan APE berbasis perembangan anak dapat meningkat melalui kegiatan kelompok belajar APE.

Penelitian ini diharapkan dapat memberikan semangat belajar kelompok kepada para mahasiswa dalam meningkatkan kompetensinya terkait desain APE serta memberi masukan kepada para pendidik untuk memperhatikan kualitas dan profesionalitas calon guru PAUD dalam hal mengembangkan APE.

\section{DAFTAR PUSTAKA}

Depdiknas, U. U. R. I. N., \& No, R. I. (2003). Tahun 2003 tentang sistem pendidikan nasional. Jakarta: Depdiknas.

Bukaliya, R., \& Mubika, A. K. (2015). The Study Group Learning Strategy in Open and Distance Learning: Students 'Perspectives. 2(5), 43-51.

Dr.Sirajul Haque. (2015). Impact of Group-study and Self-study on Learning Abilities of Students at the University Level. International Journal of Case Studies, 4(2015-02), 63-67.

Gabriel Guyton. (2011). ERIC - Using Toys to Support Infant-Toddler Learning and Development, Young Children. 66, 50-54.

Gielen, M. A. (2010). Essential concepts in toy design education: Aimlessness, empathy and play value. International Journal of Arts and Technology, 3(1), 4-16. https://doi.org/10.1504/IJART.2010.0 30490

Ginsburg, K. R., Shifrin, D. L., Broughton, D. D., Dreyer, B. P., Milteer, R. M., Mulligan, D. A., Nelson, K. G., Altmann, T. R., Brody, M., Shuffett, M. L., Wilcox, B., Kolbaba, C., Noland, V. L., Tharp, M., Coleman, W. L., Earls, M. F., Goldson, E., Hausman, C. L., Siegel, B. S., ... Smith, K. (2007). The importance of play in promoting healthy child development and 
maintaining strong parent-child bonds. Pediatrics, 119(1), 182-191. https://doi.org/10.1542/peds.20062697

Gökçe, E. (2011). The influence of group studies techniques upon teaching \& learning process in elementary education. Procedia - Social and Behavioral Sciences, 15, 3947-3956. https://doi.org/10.1016/j.sbspro.2011 .04 .399

Goldstein, J. (2012). Play in Children' S Development, Health and Well-Being. February.

Halim, F. (2018). Pelatihan Pembuatan Ape ( Alat Permainan Edukatif ) Untuk Meningkatkan Kompetensi Profesional Guru Paud Di Kecamatan Peusangan Kabupaten Bireuen. Variasi: Majalah Ilmiah Universitas Almuslim, 10(3), 6-9.

Healey, A., \& Mendelsohn, A. (2019). Selecting appropriate toys for young children in the digital era. Pediatrics, 143(1). https://doi.org/10.1542/peds.20183348

Howe, C., \& Tolmie, A. (2003). Group work in primary school science: Discussion, consensus and guidance from experts. International Journal of Educational Research, 39(1-2), 51-72. https://doi.org/10.1016/S08830355(03)00073-9

Kara, N., \& Cagiltay, K. (2020). Smart toys for preschool children: A design and development research. Electronic Commerce Research and Applications, 39, 100909. https://doi.org/10.1016/j.elerap.2019. 100909

Page, T. O. M., \& Thorsteinsson, G.
(2017). Research Papers Designing Toys To Support Children' $S$ Development By. 11(2).

Petress, K. C. (2004). The benefits of group study. Education, 124(4), 587589.

Pusari, R. W., \& Info, A. (2014). Increasing Creativity on Early Childhood Education Teachers through Educational Toys. Indonesian Journal of Early Childhood Education Studies, 3(2), 108-113. https://doi.org/10.15294/ijeces.v3i2.9 483

Safiah, I. (2015). Peningkatan Kemampuan Mahasiswa Dalam Mendesain Dan Mengembangkan Alat Permainan Edukatif (Ape) Melalui Lesson Study Pada Mata Kuliah Teknologi Pembelajaran Anak Usia Dini (Aud). 9(2), 104-117. https://doi.org/10.13170/jp.9.2.2881

Sahjat, S. (2018). ( Ape ) Playdough Sebagai Sumber Belajar. 25-29.

Sofroniou, A., \& Poutos, K. (2016). Investigating the Effectiveness of Group Work in Mathematics. Education Sciences, 6(4), 30. https://doi.org/10.3390/educsci60300 30

Trawick-Smith, J., Russell, H., \& Swaminathan, S. (2011). Measuring the effects of toys on the problemsolving, creative and social behaviours of preschool children. Early Child Development and Care, 181(7), 909-927. https://doi.org/10.1080/03004430.201 0.503892 